\title{
CONDIÇÕES DE TRABALHO DOCENTE NA ESCOLA PÚBLICA DE TEMPO INTEGRAL
}

\author{
Samanta Antunes Kasper ${ }^{1}$, Renata Portela Rinaldi ${ }^{2}$ \\ ${ }^{1}$ Mestre pelo Programa de Pós-Graduação em Educação da Universidade Estadual Paulista - UNESP, Campus de \\ Presidente Prudente. ORCID iD: https://orcid.org/0000-0002-4599-3996. E-mail: samanta kasper@hotmail.com \\ ${ }^{2}$ Doutora em Educação pela Universidade Federal de São Carlos - UFSCar. Professor Associado do Departamento de \\ Educação e no Programa de Pós-Graduação em Educação da Universidade Estadual Paulista - UNESP. ORCID iD: \\ https://orcid.org/0000-0001-7772-6705. E-mail: renata.rinaldi.unesp@gmail.com
}

\section{RESUMO}

O artigo é um recorte da pesquisa de Mestrado intitulada "Mal-estar no trabalho docente na escola pública de tempo integral" que aborda a complexidade do mal-estar docente entre os professores em exercício na rede pública de ensino por meio do Programa de Educação Integral no município de Presidente Prudente, Cidadescola. Nesta produção, tivemos como objetivo investigar e analisar as condições de trabalho dos professores que atuam com a jornada ampliada no Programa. Adotou-se a abordagem qualitativa de pesquisa em educação e, mais especificamente, a pesquisa de campo. Como instrumentos de coleta de dados foram utilizados o questionário e a entrevista semiestruturada. 0 procedimento de análise dos dados pautou-se proposta de Miles, Huberman e Saldaña (2014), sistematizada por meio da (1) condensação dos dados, (2) apresentação dos dados e (3) elaboração e verificação da conclusão. Os resultados revelaram que três categorias referentes as condições de trabalho dos professores prevaleceram nas falas dos participantes da pesquisa: participação docente no processo de implantação do Programa de Educação Integral Cidadescola; infraestrutura escolar e realização do trabalho docente e condições organizacionais, sociais e econômicas dos professores. A análise nos permitiu concluir que, as condições de trabalho docente dos professores que atuam no Programa Cidadescola carecem de aprimoramento. Nesse sentido, é necessário atentar-se para a relação entre as condições de trabalho e os efeitos sobre a saúde dos professores, o sofrimento no trabalho e a qualidade de vida dos professores.

Palavras-chave: Trabalho docente. Condições de trabalho docente. Escola pública. Educação em tempo integral.

\section{TEACHER WORKING CONDITION IN FULL-TIME PUBLIC SCHOOL}

\section{ABSTRACT}

This article is an excerpt from the Master's research entitled "Malaise in teacher work in full-time public school" that addresses the complexity of teacher malaise among teachers in the public school system through the Cidadescola Integral Education Program in the municipality of Presidente Prudente. We aimed to investigate and analyze the working conditions of teachers who work full-time in the refered Program. The qualitative approach was used as the methodological design of the study, more specifically, the field research. As instruments of data collection the questionnaire and the semi-structured interview were used. The data analysis procedure was based on the proposal of Miles, Huberman and Saldaña (2014), systematized through 1) data condensation, (2) data display, and (3) conclusion drawing/verification. The results showed that three categories related to teacher working conditions prevailed, namely: teacher participation in the process of implementation of the Cidadescola Integral Education Program; school infrastructure and teacher work development and organizational, social and economic conditions of teachers. We concluded that teacher working conditions at the Cidadescola Program demand some improvement. It is necessary to pay attention to the relationship between working conditions and effects on teachers' health, suffering at work and teachers' quality of life.

Keywords: Teacher work. Teacher working conditions. Public school. Full-time education; 


\section{CONDICIONES DE TRABAJO DOCENTE EN LA ESCUELA PÚBLICA DE TIEMPO COMPLETO}

\section{RESUMEN}

El artículo es un extracto de la investigación de Maestría titulada "Malestar en el trabajo docente en la escuela pública de tiempo completo" que aborda la complejidad del malestar docente entre los mestros del sistema escolar público a través de la Educación integral en el municipio de Presidente Prudente, Cidadescola. En esta producción, nuestro objetivo fue investigar y analizar las condiciones de trabajo de los maestros que trabajan con la jornada laboral extendida en el Programa. Adoptamos el enfoque cualitativo para la investigación en educación y, más específicamente, la investigación de campo. Los instrumentos de recolección de datos utilizados fueron el cuestionario y la entrevista semiestructurada. El procedimiento de análisis de datos se basó en la propuesta de Miles, Huberman y Saldaña (2014), sistematizado a través de (1) condensación de datos, (2) presentación de datos y (3) elaboración y verificación de la conclusión. Los resultados revelaron que tres categorías con respecto a las condiciones de trabajo de los docentes prevalecieron en las respuestas de los participantes: participación docente en el proceso de implementación del Programa de Educación Integral Cidadescola; infraestructura escolar y desempeño del trabajo docente y condiciones organizativas, sociales y económicas de los docentes. El análisis nos permitió concluir que las condiciones de trabajo docente de los maestros que trabajan en el Programa Cidadescola necesitan mejorar. En este sentido, es necesario prestar atención a la relación entre las condiciones de trabajo y los efectos sobre la salud, el sufrimiento en el trabajo y la calidad de vida de los docentes.

Palabras clave: Trabajo docente. Condiciones de trabajo docente. Escuela pública. Educación en tiempo completo.

\section{INTRODUÇÃO}

$\mathrm{Na}$ última década, vimos emergir, a proposta de educação [de tempo] integral como uma alternativa para a oferta de uma educação pública de qualidade. Apesar de o tema vir logrando visibilidade na realidade educacional atualmente, ele não teve suas origens na atualidade, visto que a defesa da educação integral se dá desde as décadas de 20 e 30 do século XX (CAVALIERE, 2010).

A concepção de educação integral como política pública para educação nacional começa a se caracterizar, do ponto de vista legal, a partir do disposto na Constituição Federal de 1988 (CF/88). A partir daí outras legislações passaram não só a reafirmar a concepção de educação integral, mas também a traçar metas e estratégias para a sua concretização, sendo a ampliação da jornada escolar um dos meios encontrados para viabilizar esse propósito. 0 aumento da carga horária escolar vem sendo pauta de crescente debate desde a publicação da Lei de Diretrizes e Bases da Educação Nacional (LDBEN) no. 9394/96, que destaca a ampliação progressiva da jornada escolar (BRASIL, 1996).

Posteriormente, o tempo integral foi abordado na Lei no 10.172/2001, que estabeleceu - Plano Nacional de Educação (PNE) para o decênio 2001-2010. O PNE avançou para além do texto da LDBEN, pois apresentou a educação em tempo integral como objetivo do Ensino Fundamental e, também, da Educação Infantil. No que tange ao ensino fundamental, determinou a ampliação progressiva da jornada escolar para um período de, pelo menos, 7 horas diárias (BRASIL, 2001).

$O$ Fundo de Manutenção e Desenvolvimento da Educação Básica e de Valorização dos Profissionais da Educação (FUNDEB) regulamentado em 2007 por meio do Decreto 6253/2007 tem como objetivo destinar recursos para todas as etapas da Educação Básica Pública, incluindo pela primeira vez, recursos para as matrículas em tempo integral. Considerando a distribuição dos recursos do FUNDEB, fez-se necessário definir o conceito de educação em tempo integral, estabelecendo um limite mínimo de tempo associado à jornada escolar, a fim de que os governos municipais e estaduais pudessem receber os recursos referentes às matrículas em tempo integral. Dessa forma, o Decreto 6253/2007 regulamentou a Lei no 11.494 de 2007 e definiu a educação básica em tempo integral como sendo a "[...] jornada escolar com duração igual ou superior a sete horas diárias, durante todo o período letivo, compreendendo o tempo total que um mesmo 
aluno permanece na escola ou em atividades escolares" (BRASIL, 2007a, art. 4ㅇ).

Também no ano de 2007 foi aprovado o Plano de Desenvolvimento da Educação (PDE), o qual imbrica ações para os diferentes níveis, modalidades e etapas da educação nacional, visando à construção de uma "visão sistêmica da educação" (BRASIL, 2007b, p. 9). Juntamente com o PDE, o Governo Federal lançou por meio do Decreto Lei no 6094/2007, o Plano de Metas Compromisso Todos Pela Educação. É possível verificar no Art. 20 do Plano de Metas Compromisso Todos Pela Educação, diretrizes voltadas para a educação integral e/ou para ampliação do tempo na escola.

Dessa forma, é possível notar que é um desafio, desde longa data, garantir às crianças e adolescentes uma formação escolar que seja produtora de cidadania. A proposta de educação de tempo integral apresenta-se como uma possibilidade para que esse e outros objetivos sejam alcançados. Nesse cenário, o Ministério da Educação (MEC) criou em 2007, o Programa Mais Educação (PME), uma das ações previstas no PDE, instituído pela Portaria Interministerial no 17/2007 e regulamentado em 2010, pelo Decreto 7.083/10. O mesmo foi considerado uma política educacional de indução de uma educação integral nas escolas brasileiras.

Devido ao amplo debate que se instalou e as diversas experiências que foram se desenvolvendo no território brasileiro, apontavase cada vez mais para a necessidade de uma política pública para a ampliação da jornada escolar na perspectiva da educação integral. Nesse sentido, a temática ganhou destaque no atual PNE correspondente ao decênio 2014-2024, conforme a Lei 13.005/14.

No ano de 2016, o Brasil teve uma grave crise política que culminou com o impeachment da presidenta eleita, aprovado pelo senado federal no dia 31 de agosto daquele ano. Após, o executivo nacional foi assumido interinamente pelo então vice-presidente no período de 01 de setembro de 2016 a 31 de dezembro de 2018, período no qual aprofundou a desestabilização e a incerteza da continuidade das políticas públicas educacionais e programas, incluindo o PME. De modo que, em 2016 o PME foi interrompido, sendo retomado no final do mesmo ano com nova roupagem, recebendo a nomenclatura de Programa Novo Mais Educação (PNME), descaracterizando e descontinuando a proposta original criada pelos governos antecessores.

Tendo em vista que a ampliação do tempo escolar amplia também as responsabilidades e o trabalho dos professores, é necessário pensar sobre as condições para o desenvolvimento deste trabalho, mais especificamente torna-se imprescindível a reorganização e melhoria de elementos materiais e não materiais. As condições de trabalho conforme Oliveira e Vieira (2012) dizem respeito à forma que o trabalho está organizado e abarcam aspectos como:

[...] a divisão das tarefas e responsabilidades, a jornada de trabalho, os recursos materiais disponíveis para o desempenho das atividades, os tempos e espaços para a realização do trabalho, até as formas de avaliação de desempenho, horários de trabalho, procedimentos didático-pedagógicos, admissão e administração das carreiras docentes, condições de remuneração, entre outras. As autoras explicam que, as condições de trabalho abrangem também "a divisão social do trabalho, as formas de regulação, controle e autonomia no trabalho, estruturação das atividades escolares, a relação número de alunos por professor" (OLIVEIRA; VIEIRA, 2012, p. 157).

Ainda, Oliveira e Vieira (2012) enfatizam que a análise sobre o trabalho deve considerar o momento econômico, histórico e cultural que as engendram. A noção de condições de trabalho na visão de Oliveira e Assunção (2010, s/p) abarca "[...] o conjunto de recursos que possibilitam a realização do trabalho, envolvendo as instalações físicas, os materiais e insumos disponíveis, os equipamentos e meios de realização das atividades e outros tipos de apoio necessários, dependendo da natureza da produção". Todavia, de acordo com as autoras, elas não se restringem apenas ao posto ou local onde o trabalho é 
desenvolvido ou à execução do trabalho em si, mas dizem respeito também às relações das condições objetivas de realização do mesmo e às condições de emprego, como por exemplo, as formas de contratação, remuneração, carreira e estabilidade.

Considerando que a implantação das escolas de tempo integral no país tem aumentado significativamente, mas nem sempre há o planejamento adequado para garantir uma expansão qualitativa no sistema de ensino, julgase necessário o olhar cuidadoso para o professor que atua na escola com a jornada ampliada, pois se configura como sujeito que ocupa papel central desta [transform]ação que vem ocorrendo no sistema educacional brasileiro. Nesse sentido, o presente trabalho buscará investigar e analisar as condições de trabalho dos professores que atuam com a jornada ampliada no município de Presidente Prudente no Programa de Educação Integral Cidadescola.

\section{DELINEAMENTO METODOLÓGICO}

A realização do presente trabalho se deu utilizando a abordagem qualitativa, com a preocupação em circunscrever o objeto investigado tendo em vista as características e as possibilidades oferecidas por esse tipo de pesquisa. A pesquisa qualitativa pressupõe $o$ diálogo com a realidade a qual se pretende investigar. Nesse sentido, a pesquisa de campo apresenta-se como uma possibilidade para o estabelecimento dessa articulação. De acordo com Minayo (2009), o trabalho de campo permite que o pesquisador se aproxime da realidade sobre a qual formulou o seu problema, bem como permite que ele estabeleça uma interação com os atores que constituem essa realidade, proporcionando, assim, um conhecimento empírico valioso para quem desenvolve pesquisa.

Desenvolvemos o trabalho de campo no município de Presidente Prudente, que possui um programa próprio de educação integral. Após a autorização para desenvolver o estudo nas escolas do município por parte da Secretaria Municipal de Educação de Presidente Prudente, obtivemos, em 23 de fevereiro de 2018, a aprovação do projeto de pesquisa pelo Comitê de Ética em Pesquisa com Seres Humanos (CEP) da Universidade Estadual Paulista "Júlio de Mesquita Filho" (Unesp) da Faculdade de Ciências e Tecnologia (FCT), Presidente Prudente - (CAAE: 80160117.1.0000.5402) e iniciamos a etapa de coleta de dados empíricos.
O trabalho de campo teve início com a apresentação do projeto de pesquisa no evento de lançamento do Programa Cidadescola 2018 no dia 22 de março de 2018 no Centro de Formação Permanente dos Profissionais da Educação (CEFORPPE). Entretanto, devido à baixa adesão dos professores, alterarmos a estratégia para a coleta dos dados.

Desse modo, a partir do mês de agosto, iniciamos as visitas às escolas com o intuito de convidar, novamente, os professores a participar da pesquisa. Visitamos 15 escolas de tempo integral da rede municipal de Presidente Prudente do total de 30 . 0 critério de seleção das escolas se deu principalmente pelo fato de algumas delas já terem colaborado anteriormente com estudos desenvolvidos pela orientadora desta pesquisa e, a nosso ver, poderiam aceitar contribuir com a presente investigação. Outro critério de seleção referiu-se à localização das escolas. Optamos por selecionar escolas em múltiplos bairros, uma vez que, por estarem localizadas em contextos diferentes, poderiam apresentar realidades distintas devido às demandas e necessidades locais.

Utilizamos inicialmente para a coleta dos dados o questionário, composto majoritariamente por perguntas abertas, que visou delinear o perfil das participantes da pesquisa, bem como identificar suas concepções sobre a Escola de Tempo Integral (ETI) no seu local de trabalho e aspectos do trabalho docente na perspectiva investigada. Para essa etapa, alguns encontros foram previamente agendados com as professoras articuladoras ${ }^{1}$, enquanto outros aconteceram sem agendamento prévio. 0 fato de os professores possuírem horários variados de trabalho muitas vezes dificultou a possibilidade de reunirmos esses profissionais para apresentá-los diretamente a proposta. Logo, quando o contato direto com os professores não foi possível, apresentávamos a proposta à professora articuladora e, em alguns casos, à diretora da escola, e posteriormente entregávamos os questionários e o Termo de Consentimento Livre e Esclarecido (TCLE) para que elas os repassem aos professores. Algumas escolas possuíam um elevado número de

\footnotetext{
A professora articuladora possui a função de coordenar o Programa Cidadescola na unidade escolar, administrando as oficinas, orientando os profissionais envolvidos (professores, estagiários, oficineiros, entre outros), bem como manter a equipe gestora informada e auxiliá-la em questões que dizem respeito ao Programa. Ainda, acompanham os alunos nas oficinas que ocorrem dentro e fora da escola.
} 
oficineiros trabalhando no Programa Cidadescola, desse modo, nessas escolas, o questionário também foi entregue a esse grupo. Do total de 66 questionários entregues, 23 foram devolvidos, sendo que 2 destes estavam em branco.

Após o recolhimento dos questionários, iniciamos a etapa seguinte da pesquisa, a entrevista semiestruturada com aqueles professores que se disponibilizaram a participar. A entrevista representa um dos instrumentos básicos para a coleta de dados, dentro da perspectiva de pesquisa em Educação (LUDKE; ANDRÉ, 1986). Havia no questionário entregue aos professores um espaço para que eles disponibilizassem um contato, que foi requisitado para que posteriormente pudéssemos convidálos a participar da entrevista. Do total de 21 professores que responderam ao questionário, 10 disponibilizaram seus contatos. Desse modo, enviamos um e-mail a estes professores convidando-os a participar da entrevista. Do total de 10 professores que receberam o e-mail, 3 o responderam, indicando $O$ interesse em participar da mesma (P3, P20, P21). O dia, o horário e o local em que a entrevista aconteceu foram definidos pelas participantes de acordo com a disponibilidade de cada um. Ainda, as entrevistas foram gravadas em áudio com a autorização prévia das participantes. Em seguida, os questionários e as entrevistas foram transcritos, sendo a transcrição das entrevistas adequada conforme as normas do protocolo NURC - Norma Urbana Linguística Culta, visando tornar o texto mais claro e de fácil compreensão.

Concluídas as etapas de coleta e a organização dos dados de pesquisa, iniciamos a análise dos mesmos. O tratamento, a tabulação e a análise do material se deu à partir da proposta de Miles, Huberman e Saldaña (2014), sistematizada por meio da (1) condensação dos dados, (2) apresentação dos dados e (3) elaboração e verificação da conclusão. A condensação dos dados diz respeito ao processo de selecionar, focar, simplificar abstrair e/ ou transformar os dados que aparecem no corpus das transcrições das entrevistas, notas de diário campo, documentos e outros materiais empíricos. Condensar os dados implica em deixálos mais fortes. O termo "condensação" opõe-se ao termo "redução", visto que esse último sugere que se está enfraquecendo ou perdendo dados (MILES; HUBERMAN; SALDAÑA, 2014, tradução nossa). A próxima etapa configura-se na apresentação dos dados, quando esses são organizados através de tabelas, gráficos, quadros ou textos. Os autores ressaltam a importância da escolha da disposição dos dados, uma vez que esse aspecto influencia diretamente na qualidade da análise. (MILES; HUBERMAN; SALDAÑA, 2014, tradução nossa). Finalmente, a elaboração e verificação da conclusão. Para Miles, Huberman e Saldaña (2014, tradução nossa), o pesquisador deve interpretar o significado dos dados coletados desde o início da coleta, mantendo-se aberto e cético às descobertas. Em um primeiro momento, a conclusão é vaga e, no decorrer da pesquisa, é fundamentada, até que finalmente, através da verificação, seja possível validá-la. A verificação pode ser feita pelo próprio pesquisador, que irá rever o material coletado e suas anotações de campo, ou pode ser realizada por terceiro, que terá a tarefa de revisar e argumentar os achados da pesquisa, avaliando, assim, a sua credibilidade.

\section{RESULTADOS E DISCUSSÃO}

A partir das análises dos dados verificamos a emergência de três categorias que predominaram nas falas dos docentes, a saber: participação docente no processo de implantação do Programa de Educação Integral Cidadescola, infraestrutura escolar e realização do trabalho docente e condições organizacionais, sociais e econômicas dos professores.

Os docentes são os principais responsáveis por colocarem em prática as políticas educacionais. Nesse sentido, os processos de tomadas das decisões políticas deveriam abranger a participação dos mesmo desde o início das discussões. Entretanto, na realidade, o que se observa é um distanciamento entre o planejamento e a execução das tarefas, o que implica na fragmentação do trabalho docente. Nesse sentido, Giroux $(1987$, p. 9) alerta para o fato de que:

[...] o exercício de
magistério vem sendo
crescentemente
subordinado à divisão
técnica e social do
trabalho, o que, ou amarra
o professor aos ditames de
especialistas que foram
removidos do contexto da
sala de aula, ou serve para
aumentar a distância
política entre aqueles que
controlam a escola e
aqueles que trabalham


dia-a-dia, de fato, com os estudantes e com os currículos.

Desse modo, o professor se vê submetido a uma política verticalizada, onde o poder é exercido "de cima para baixo", aspectos esses que trazem implicações negativas à efetivação das propostas. Essa questão foi abordada por Silva (2016) que percebeu que a maioria dos envolvidos no projeto de educação integral do município investigado, não possui conhecimento da intencionalidade da proposta, uma vez que não houve um planejamento educacional adequado e a inclusão dos agentes envolvidos nas etapas antecedentes à implantação. Concluiu ainda que, o professor não é visto como protagonista, muito pelo contrário, notou-se que a participação deles se limita à execução das reformas. Nesse sentido, considerando a importância da inclusão do professor nas tomadas decisões dos profissionais que atuam no "chão da escola", perguntamos as docentes como o processo de implantação do Programa Cidadescola ocorreu e se elas se sentiram envolvidas nesse processo. Esse elemento foi mencionado 22 vezes pelas participantes da pesquisa.

A maior parte das docentes $(40,90 \%)$ ou não responderam à pergunta ou abordaram outros aspectos que não estavam diretamente relacionados à implantação do Programa Cidadescola, direcionando as respostas principalmente para o fato de o Programa estar contribuindo com a aprendizagem e com o desenvolvimento das habilidades dos alunos. $\mathrm{O}$ fato de quase metade dos sujeitos terem interpretado a questão por este viés, nos leva a indagar o que levou as docentes a responderem a pergunta nessa perspectiva. Talvez a questão tenha sido formulada de modo que tenha ocorrido uma falha ou limitação para a sua compreensão, apesar da realização dos procedimentos de pré-teste. Por outro lado, talvez o fato de terem dado esse direcionamento às respostas ao serem questionadas acerca de como ocorreu a implantação da escola de tempo integral, nos leva a subentender o desconhecimento desse processo.

O total de seis professoras $(27,27 \%)$ informou que não fazia parte da unidade escolar ou do Programa durante o processo de implantação, enquanto três responderam $(13,63 \%)$ que se sentiram envolvidas no processo:
Foi muito positiva. Participei acompanhando a organização das oficinas, ou seja, na escolha das oficinas que seriam desenvolvidas e na organização dos espaços /tempos necessários $(Q$, P2).

Uma das professoras que afirmou ter participado do processo indicou que a implantação foi "difícil". Similarmente, outra professora mencionou que o processo foi "conturbado", totalizando 9,09\% das respostas:

Foi um pouco conturbado, pois era tudo muito novo ainda não tínhamos muito esclarecimento de como tudo se desenvolveria $(Q$, P11).

Por outro lado, duas professoras $(9,09 \%)$ afirmaram não ter participado do processo. Assim como já afirmava Giroux (1987), no âmbito da escola as decisões podem ser também verticalizadas e não envolver o coletivo, como indica a narrativa da professora abaixo:
A implantação não participei, ficou a cargo da direção. Fui coordenadora e depois de saber os objetivos da oficina tive que procurar atividades $(\mathrm{Q}, \mathrm{P} 3)$.

O fato de a implantação ter ficado a cargo da direção da escola demonstra que a gestão adotada pela instituição não se configura como sendo de natureza participativa e democrática, desse modo, não traduz os desejos e as reivindicações dos profissionais que nas escolas atuam. $\mathrm{O}$ tipo de gestão assumido pelas escolas públicas constitui-se como um fator que pode consolidar ou limitar o trabalho docente, influenciando até mesmo na saúde psíquica do professor (BATISTA; ODELIUS, 2006). Nesse sentido, uma gestão tradicional, em contraponto a gestão democrática, gera exaustão emocional nos professores e influencia negativamente na autoestima, uma vez que suas vozes são silenciadas e seus anseios desconsiderados.

Das escolas que participaram da pesquisa, percebemos um número reduzido de professoras que indicaram o não envolvimento no processo de implantação da proposta da escola de tempo integral. De qualquer forma, 
cabe destacar que, o fato de as professoras estarem à margem neste processo pode prejudicar o êxito do Programa. Nesse sentido, Gadotti (2009) enfatiza a importância do planejamento, da participação e formação dos atores envolvidos no processo de implantação da escola de tempo integral:

O tempo integral, para ser efetivo, deve ser opção voluntária da escola ou de um conjunto de escolas. Não pode ser imposto. As escolas precisam ter condições para implantar essa inovação educacional. Precisam participar, desde o início, da discussão dessa nova política educacional e acompanhar seu desenvolvimento. A implantação do tempo integral nas escolas exige preparo técnico-político e formação, tanto dos pais quanto dos alunos, dos professores e demais funcionários da escola (GADOTTI, 2009, p. 36).

Corroboramos Gadotti (2009), uma vez que a verticalização das políticas, muitas vezes impossibilita a participação dos atores no processo de planejamento dos projetos, resultando na falha da implementação, tendo em vista que os formuladores de política não compreendem as reais condições de trabalho sob as quais os profissionais das escolas estão submetidos. Na mesma direção, Hypolito (2014) ressalta que é necessário haver uma interlocução entre os atores na formulação de política educacional, caso contrário ela estará fadada ao fracasso. Em suas palavras: "Ou se discute com a comunidade escolar e com a sociedade qual é, afinal, o projeto de escola para o país, para o estado, para os municípios ou a tendência é de que as políticas não vão ser efetivadas" (HYPOLITO, 2014, p. 25).

Considerando que, a maior parte das respostas dadas $(40,90 \%)$ não indicaram, de fato, como ocorreu o processo de implantação, não podemos afirmar que os professores não foram envolvidos nesse processo. Entretanto, cabe enfatizar que a participação das professoras nas decisões sobre o rumo do Programa Cidadescola no município é fundamental para apontar as possibilidades e limites do projeto, além do fato de trazer implicações em diversas esferas do contexto escolar.

A infraestrutura escolar também se constitui como um elemento que possui relação direta com as condições de trabalho dos professores. A ausência ou insuficiência do suporte estrutural adequado pode implicar não apenas no desenvolvimento e precarização do trabalho docente, mas também no desenvolvimento da aprendizagem dos alunos e consequentemente, nos resultados de desempenho observados nos exames de avaliação em larga escala. Ainda, se faz necessário destacar o fato de os alunos e as instituições serem submetidos ao mesmo sistema de avaliação, sem considerar as condições de funcionamento e as particularidades das escolas. Essas políticas desconsideram os diversos fatores que afetam o processo de ensino-aprendizagem e responsabilizam os professores pelos resultados dos alunos, o que pode provocar ou agravar o mal-estar docente.

Adotaremos o conceito de infraestrutura segundo Batista e Odelius (2006) que diz respeito as ferramentas dos professores que permitem a execução do seu trabalho. As ferramentas do trabalho docente abrangem as seguintes dimensões: recursos básicos (carteiras, quadronegro, giz), materiais de apoio ao ensino (aparelho de som, biblioteca, computadores, material didático), recursos que favorecem melhores condições de trabalho (espaço para descanso, sala dos professores, armário para os docentes), além das condições ambientais (barulho, conservação do edifício, umidade, iluminação).

Entretanto, apesar da importância atribuída à infraestrutura das escolas para a melhoria da qualidade do ensino ofertado, estudos demonstram que a infraestrutura das escolas públicas brasileiras não condiz com as necessidades dos professores, tampouco com as dos alunos. Batista e Odelius (2006), por exemplo, ao considerarem os valores alcançados nas dimensões que compõem a definição de infraestrutura observaram que as escolas funcionam mais sobre os materiais básicos, o que é insuficiente. De acordo com as autoras, uma escola que possui ou oferece apenas o mínimo de materiais de apoio ao ensino faz com que o professor trabalhe dobrado, uma vez que este deve preparar suas aulas sem os instrumentos necessários ou fornecer ele mesmo esses instrumentos atribuindo-lhe mais uma tarefa e 
reforçando a minimização do Estado na responsabilidade para com a educação.

Em nossa pesquisa a questão $d a$ infraestrutura compareceu 36 vezes na fala das docentes. A ausência de recursos materiais totalizou $13,88 \%$ das respostas das professoras, aspecto esse ilustrado nos trechos que seguem:

Trabalhar com o que temos (falta de material) $(\mathrm{Q}, \mathrm{P} 2)$.

Uso de material que o programa não fornece $(Q$, P7).

Por sua vez, a falta de espaços e/ou espaços adequados equivale a porcentagem de $33,33 \%$. Quando a infraestrutura da escola é deficiente os professores encontram dificuldades para desempenhar as atividades que haviam planejado, adicionalmente, as condições físicas e o ambiente escolar são variáveis que apresentam um forte impacto no desempenho dos alunos, estando a infraestrutura, portanto, diretamente relacionada com a qualidade do ensino (BARBOSA; FERNANDES, 2001). A P3 aponta em sua narrativa alguns desses elementos:

$$
\begin{aligned}
& \text { Então, assim, até } \\
& \text { professores de outros } \\
& \text { locais que vão trabalhar lá } \\
& \text { na escola, falam assim "eu } \\
& \text { dava aula num lugar que } \\
& \text { antigamente era um } \\
& \text { banheiro", lá na escola } \\
& \text { não tem, assim, a gente } \\
& \text { sempre teve sala mesmo, } \\
& \text { né? [...] lá na escola a } \\
& \text { gente tem esse espaço } \\
& \text { que teve a construção do } \\
& \text { anexo, então tem esse } \\
& \text { espaço. No primeiro ano, } \\
& \text { antes de construir isso eu } \\
& \text { já dei aula no salão da } \\
& \text { igreja eu trabalhava lá, lá } \\
& \text { que eu trabalhava com a } \\
& \text { oficina, é ruim, as vezes } \\
& \text { você quer levar alguma } \\
& \text { coisa pesada, então assim, } \\
& \text { lá na escola pra material, } \\
& \text { organização é melhor né? } \\
& \text { mas na escola cada um } \\
& \text { tem sua salinha né? o } \\
& \text { professor que dá aula na } \\
& \text { quadra tem a quadra } \\
& \text { disponível pra ele e tudo } \\
& \text { (E, P3). }
\end{aligned}
$$

O trecho da fala da P3 indica a condição precária em que alguns dos seus colegas desenvolvem as atividades, como em um local que antigamente era um banheiro. Por sua vez, a sua realidade é mais cômoda, uma vez que na escola em que atua há locais adequados para a realização das aulas. A professora menciona ainda que inicialmente dava aulas no salão da igreja e que isso dificultava a realização de algumas atividades. Entretanto, o fato da mesma ter dado aulas no salão da igreja pode estar vinculado à concepção de território educativo do Programa Cidadescola.

Há ainda professoras que mencionaram o fato de realizarem ajustes e adaptações para o desenvolvimento das atividades no Programa, enquanto outras enfatizaram o fato de espaço ser dividido com o ensino regular, resultando em negociações para a utilização do mesmo.

A escola é pequena. Como temos o ensino regular nos dois períodos às vezes choca, mas negociamos $(\mathrm{Q}, \mathrm{P} 4)$.

Ruim, utilizamos o espaço físico destinado/programado para outra atividade, fazemos adaptação/ ajuste para que as crianças tenham um lugar para aprender ( $\mathrm{Q}, \mathrm{P} 15)$.

O fato de algumas docentes realizarem adaptações e ajustes para desenvolverem seu trabalho, conforme apresentado nas falas da P15 traz à tona o discurso da "criatividade" que tanto é exigido dos professores como forma de suprir as lacunas e dificuldades cotidianas. A P20 possui a seguinte visão acerca desse assunto:

[...] Quando a gente trabalha com educação a gente precisa ser criativo porque ficar pensando eu não tenho verbas, eu tenho que ir lá na cidade comprar, pronto, não eu acho assim. [...] eu fico até triste quando escuto um professor falar assim "ah, eu até tentei fazer aquele projeto", "ah, mas eu não tive respaldo os gestores, não me forneceram", gente não é ninguém te 
fornecer, é você olhar pra aquele papel, olha eu vou tentar trabalhar isso que eu tenho ali, que eu posso contribuir pra levar isso [...]. Então eu penso que hoje que, eu falo assim, eu preciso de algo no Cidadescola? não eu não preciso ma-te-ri-al-mennte, eu preciso de professores criativos [...] (E, P20).

Não corroboramos o discurso da P20, pois na nossa concepção, não é papel do professor empenhar-se para que as crianças "tenham um lugar para aprender", é dever das políticas educacionais proporcionar o devido espaço e as condições estruturais necessárias para que essa aprendizagem se efetive. 0 discurso da criatividade transfere uma obrigação do Estado para o professor, fazendo com que mais uma função lhe seja atribuída.

Ainda, de acordo com a fala das professoras, o atendimento concomitante de alunos em jornada de tempo ampliada e dos turnos regulares faz com que os docentes recorram à espaços improvisados e a negociações para a utilização dos mesmos, restringindo as suas opções por falta de recursos físicos e materiais para atender aos estudantes-alvo da jornada ampliada.

Adicionalmente, $0 \quad$ atendimento simultâneo de alunos do turno regular e da jornada ampliada influencia na quantidade do número de alunos na escola, aspecto esse mencionado por $13,88 \%$ das docentes. O maior número de alunos, somado ao espaço restrito, pode prejudicar a harmonia da escola, aumentando, por exemplo, o ruído no ambiente escolar.

A questão do barulho é abordada por duas professoras $(5,55 \%)$ que diz ter a impressão que "a escola fica mais agitada e barulhenta" $(Q$, P3). Para o P21 o barulho é uma das coisas que mais lhe estressa no trabalho, uma vez que um ambiente ruidoso atrapalha o desenvolvimento de seu trabalho e a aprendizagem dos alunos:

[...] outra coisa que me estressa, trabalhar em local barulhento, isso me incomoda demais, salas que ficam... ou que não são adequadas. [...]então tem que ser no local mais silencioso, for um local barulhento as crianças elas vão querer fazer barulho também e se do lado tiver um barulho elas vão dispersar para poder fazer o barulho também, então isso me estressa também [...] alguns alunos que estão na quadra, tem outros que estão no pátio fazendo outra atividade [...] então junta todos esses ruídos e forma um barulho muito grande, fora a rua que passa os carros que tem outros ruídos né? ( $E, P 21)$.

De acordo com Hypolito (2012, p. 224) "[...] as condições de ruídos são significativas no sentido de que há uma perturbação, como no que se refere ao ruído originado na sala de aula, fora da sala de aula, fora da unidade escolar". De modo complementar, o excesso de barulho no ambiente escolar, interfere no processo de ensino e aprendizagem escolar, além de prejudicar saúde dos alunos e dos docentes.

No que diz respeito ao espaço destinado ao descanso e ao trabalho individual ou coletivo da equipe, aproximadamente $62 \%$ dos professores alegaram que as escolas em que atuam possuem espaço adequado para essas ações, enquanto $33,33 \%$ afirmaram que as escolas não possuem determinado espaço. Duas professoras (P1 e P3) indicaram que, apesar de as escolas em que atuam proporcionarem tais espaços, elas não possuem tempo para descansar e uma (P12) enfatizou que o intervalo entre o turno regular e o início do programa "fica a desejar". A ausência de um espaço próprio para o descanso e para o trabalho individual ou em grupo influencia negativamente no trabalho do professor, visto que o mesmo necessita de um local apropriado para "recuperar as energias" e para desenvolver sua formação. $O$ fato de um número razoável de professoras mencionarem a inexistência desse espaço nos faz indagar em qual local e se a formação continuada coletiva desse sujeitos vem acontecendo.

Por outro lado, 33,33\% das professoras citaram a obtenção de recursos relacionados à infraestrutura foi uma das principais conquistas obtidas pela escola desde a implantação do Programa, conforme as passagens a seguir: 
Tivemos a oportunidade de adquirir novos materiais para as oficinas e consequentemente melhorou a estrutura da escola nestes aspectos $(Q$, P11).

[...] então você vê, por exemplo, ar condicionado em todas as salas [...] coisas que às vezes a gente nunca imaginava conseguir né? impressora... [...] o Cidadescola ele trouxe bastante verba para escola, ele trouxe assim... para comprar coisas assim, por exemplo, o que foi construído de novo foi com o dinheiro do Cidadescola, muitos joguinhos, muitos materiais que tem aí foi com o dinheiro do Cidadescola [...] (E, P3).

Nos anos anteriores, recebíamos verba do FNDE que foram designadas à compra de vários recursos, materiais de qualidade que permanece no uso da escola em geral $(Q, P 9)$.

Embora o Programa Cidadescola tenha viabilizado recursos de infraestrutura às escolas, principalmente quando o mesmo era vinculado ao governo federal, $61,90 \%$ das professoras afirmaram ter feito o uso do próprio salário para arcar com alguma despesa de material que não estava disponível. Algumas docentes esclareceram que a quantia gasta era pouco ou insignificante, como é o caso da P5 e da P11. Entretanto, acreditamos que não é a função dos professores arcar com materiais para 0 desenvolvimento das atividades, mesmo que a quantia gasta seja mínima. É necessário o cuidado para atitudes como essa não se naturalizarem e sua gravidade ser minimizada muitas vezes até mesmo pelos próprios professores. $\mathrm{Na}$ contramão, $38,09 \%$ das professoras afirmaram nunca ter utilizado do próprio salário, entretanto, algumas precisaram utilizar-se de outros meios para conseguirem recursos. A P4 por exemplo, relatou que algumas vezes pedidos de doações são feitos às crianças. De modo similar, a P9 comentou que os professores utilizam as verbas advindas das festas e eventos promovidos pela escola.

Os dados demonstram que os fatores limitantes dos recursos físicos e materiais do Programa Cidadescola interferem no desenvolvimento das atividades e que apesar dos avanços e conquistas referentes aos recursos infraestruturais recebidos pelas escolas, principalmente no período em que o município era subsidiado pelo governo federal, esses aspectos ainda precisam ser aperfeiçoados. Apesar de o Programa Cidadescola adotar a concepção de território educativo e a prática intersetorial, entendendo os espaços da comunidade e da cidade como espaços de aprendizagem, essa prática não pode substituir o investimento na infraestrutura das escolas, visto que essas também são ambientes que educam componentes.

As condições organizacionais, sociais e econômicas dos professores também se constituem com um elemento importante na organização do trabalho docente. Essas varáveis podem funcionar tanto como fonte de insatisfação e sofrimento, quanto como fonte de satisfação e prazer. Nesse sentido, Rebolo (2012, p. 26) afirma que: "o trabalho, para ser realizado, depende de certas condições concretas e de determinadas formas de organização que podem ou não corresponder às expectativas e necessidades de quem o executa". Os aspectos organizacionais, sociais e econômicos foram mencionados 85 vezes pelas participantes de nossa pesquisa.

A carga horária e demanda laboral, elementos que compõem as condições organizacionais do trabalho docente, compareceram com uma porcentagem relativamente alta (67,05\%). Tardif e Lassard (2009, p. 111) ao discorrerem sobre a carga de trabalho dos professores analisam a temática de um ponto de vista administrativo e prescritivo. Esses pontos de vistas trazem à tona a dualidade da tarefa prescrita, que diz respeito ao que conta nos documentos normativos, e da tarefa real, tal como é realizada no processo concreto do trabalho. Os autores apresentam algumas variáveis que influenciam na carga de trabalho e na demanda laboral docente, a saber: o tempo de trabalho e o número de alunos, o tempo dedicado ao ensino com os alunos, as tarefas escolares fora das horas normais de trabalho, o 
aperfeiçoamento, entre outras (TARDIF; LASSARD, 2009).

No trecho a seguir verificamos como a demanda laboral é apresentada na fala da P20:

[...] quando eu falo em tempo integral eu não posso olhar só o lado do aluno, eu tenho que olhar também o professor [...] como eu tô enxergando esse meu professor? como eu tô sobrecarregando esse meu professor? eu acho que é nisso que a escola ela perde um pouco (E, P20).

As respostas das professoras de nossa pesquisa se voltaram principalmente para o fato da longa jornada de trabalho, conforme as respostas que seguem:

Ficar extremamente cansado por ficar o dia todo na escola $(\mathrm{Q}, \mathrm{P} 1)$.

A dedicação em tempo integral requer mais do professor, isto acaba causando um desgaste maior $(\mathrm{Q}, \mathrm{P} 2)$.

Chega novembro e eu estou morta, chega novembro e eu estou um bagaço, então assim, a carga horaria laboral é maior né? cargos monetários são bons só no holerite né? mas assim, é cansativo você ficar o dia todo na escola, o próprio ambiente né? é cansativo... eu acho... (E, P3).

As respostam mostram que o fato de os professores trabalharem em período integral gera cansaço físico e mental nos docentes. Outro elemento que pode contribuir com esses sintomas é o fato de os professores não possuírem um tempo adequado para o descanso, uma vez que o intervalo entre o regular e o início das atividades do Programa é de apenas 35 minutos. Consideramos que 35 minutos para comer e descansar é um tempo reduzido, tendo em vista que as docentes ficam na escola em tempo integral. Há ainda docentes que vendem esse tempo de descanso para cuidar das crianças, o que é um indício de precarização do trabalho docente, conforme a fala da P3:

[...] tinha professores que vendiam esse horário pra ficar lá no cantinho com as crianças e eu falei pra (nome da articuladora) "eu trabalho tudo, mas horário de descanso eu preciso, pra abaixar, pra me acalmar pra pegar a turma" então eu nunca vendi esse horário, às vezes eu ficava lá porque faltava um professor né e a escola não tinha ninguém, então eu ajudava, mas assim eu não vendo meu horário de descanso (E, P3).

Apesar de a P3 não vender o seu horário de descanso, as vezes ela necessita "abrir mão" do mesmo para auxiliar no cuidado com os alunos. Isso provavelmente influenciará no seu desenvolvimento no período da tarde, considerando que não pode descansar como o de costume.

As atividades extraclasses também foram mencionadas pelos professores como um fator desencadeante de cansaço e desgaste:
Mais trabalho em casa/ escola, mais cansaço $(Q$, P1).
O professor que trabalha no Programa agrega mais horário de trabalho a sua rotina, em casa e na escola $(\mathrm{Q}, \mathrm{P} 3)$.

A P3 destaca também que as horas que as horas de HTPC dos professores de Orientação de Estudo e Leitura (OEL) diminuíram. As HTPC's do Programa Cidadescola são utilizadas para a preparação das atividades, com a diminuição das horas de HTPC podemos inferir que os professores estejam desenvolvendo essas tarefas em suas casas. Sobre essa questão Jacinto e Hobold (2012, p. 295) afirmam que: A falta de remuneração de
horas para atividades de
planejamento e correção é
um indicador de que os
professores ricam
sobrecarregados r de
atividades para serem 
realizadas em casa. Essa situação, na maioria das vezes, reverte-se em fadiga e cansaço. Além do mais, atender às demandas institucionais que requerem deles a realização de atividades burocráticas, também se torna desgastante para muitos docentes.

Cabe destacar que as mulheres ocupam a maioria dos cargos docentes (HYPOLITO, 1999), aspecto esse que vai de encontro ao perfil das participantes de nossa pesquisa, visto que $90,47 \%$ são do gênero feminino ${ }^{2}$. Hypolito (1999) aponta que muitas professoras possuem uma tripla jornada de trabalho se considerarmos o trabalho doméstico, o trabalho desenvolvido na escola e o trabalho extraclasse. Esse elemento dificulta, por exemplo, a formação continuada das docentes que exige tempo e dedicação das mesmas.

Outro fator que pode gerar cansaço nos docentes é a questão de assumir turmas em diferentes escolas, conforme mencionado pela P10 e P20:

Eu trabalho em duas escolas, o tempo perdido entre uma escola e outra $[\ldots](Q, P 20)$.

$\mathrm{Na}$ questão de assumir sala no regular em unidades diferentes, $\mathrm{O}$ horário é bem corrido, em relação ao transporte $(Q$, P10).

De acordo com o discurso da P10, o tempo para se deslocar entre uma unidade e outra é "corrido", aspecto esse que pode ser um gerador de desgaste. Essa é a realidade de muitos professores que para completar a carga horária semanal muitas vezes necessitam assumir turmas em diferentes unidades escolares. O P21, por exemplo atuou por um período em 5 escolas e atualmente viaja para diferentes cidades da região, sendo a viagem na rodovia algo que the causa cansaço conforme a fala do professor. $\mathrm{Na}$ contramão, algumas docentes indicaram a dedicação em tempo integral como uma

\footnotetext{
${ }^{2}$ Considerando que $90,47 \%$ das participantes da pesquisa são do gênero feminino, utilizaremos em todo o artigo o termo professoras ou sinônimos no feminino para nos referirmos às mesmas.
}

vantagem, aspecto esse que traz implicações para o aproveitamento do tempo e para a quantidade de turmas assumidas pelos docentes.

A vantagem é que
podemos nos dedicar
também em tempo
integral $(Q, P 2)$.

Poder trabalhar em apenas um local, ampliar as possibilidades de trabalho na escola e menos em casa. Maior aproveitamento do tempo (Q, P11).

É importante destacar que a trajetória e as experiências docentes também podem influenciar na opinião das professoras em relação ao fato de ficarem o dia todo na escola. A P3, por exemplo, relatou que antes da começar a atuar no Programa Cidadescola ela já trabalhava com o reforço escolar. Sendo assim, estar na escola em período integral já fazia parte da sua rotina. Entretanto, apesar de já estar acostumada com a dedicação em tempo integral, a professora indicou que a sua demanda laboral aumentou devido ao fato de possuir turmas de séries variadas.

[...] o que mudou mais assim... é que eu tive que preparar mais coisas, porque no reforço as vezes a professora deixa atividade, é mais tranquilo, o que mudou foi que eu tive que preparar mais atividade, por exemplo, esse ano eu dou aula pra três turmas é... terceiro ano, quarto ano e quinto ano, então o jogo que eu dou no terceiro ano não serve pro quinto e você não pode ficar repetindo sempre a mesma coisa né? tem que ser sempre diferente, então assim, esse montante de preparar assim que é maior, mas isso de ficar o dia todo na escola isso eu já tinha já desde o começo (E, P3).

A P3 também discorreu sobre a demanda laboral em sala de aula. A docente afirmou que 
inicialmente cada turma possuía uma estagiária que auxiliava o professor. Todavia, atualmente a escola em que atua conta apenas com duas estagiárias para atender todas as turmas. Entretanto, na segunda entrevista que realizamos com a P3 a mesma contava novamente com o auxílio de um estagiário e por conta disso se diz mais satisfeita. O professor P1 também afirmou que durante suas aulas ele conta com o auxílio da articuladora e de um estagiário, sendo que os mesmos permanecem o tempo todo junto à turma. Segue a passagem:

[...] a articuladora está sempre junto ajudando o aluno que vai pro o banheiro, que sai, então tem uma grande ajuda porque o professor ele não fica sozinho dentro de uma sala de aula, tem a articuladora e tem o estagiário que também ajuda a gente, então a todo momento o aluno está sendo monitorado, então nós não temos tanto problema em questão ao mau comportamento, pode acontecer de uma criança chutar a outra e a gente passar despercebido e não ver, mas o articulador que tá sentado atrás ele vê, ou então 0 estagiário também vê, então tudo isso é relatado e facilita para o professor também (E, P21).

A narrativa do $\mathrm{P} 21$ releva que a presença do articulador e do estagiário facilita o desenvolvimento do trabalho do professor, principalmente no que tange ao manejo da disciplina dos alunos.

A burocracia também se constitui como um elemento que influência na demanda laboral dos docentes, e foi citada como uma desvantagem em ser professor em uma escola de tempo integral pela P2. Por sua vez, a P3, que atua na mesma escola que a P2 afirmou não precisar lidar com muitos aspectos burocráticos:

Burocracia eu não tenho assim muito né? A gente tem a pasta... a gente preenche, burocracia em si eu não tenho muito $(E$, P3).

Cunha (1999) alerta que a burocratização do trabalho funciona como uma forma de controle da atividade educativa. De acordo com a autora, "enquanto nas profissões com forte estatuto o controle é profissional [...], nas profissões frágeis o controle é burocrático" (CUNHA, 1999, p. 137). Ainda sobre o tema a autora complementa:

Em geral, a burocratização transparece na quantidade de tarefas complementares ao que é essencial e acabam, para fins de valorização, sendo as mais importantes na constelação das atividades. Normalmente, os resultados da ação docente podem ser definidos numericamente, e a quantidade é sempre evidencia de qualidade. Outro aspecto relevante é que em geral, a burocratização anula as diferenças contextuais, não as leva em conta, minimizando as subjetividades dos indivíduos envolvidos na profissão (CUNHA, 1999, p. 137).

A desorganização é outro aspecto que pode intensificar a demanda laboral docente uma vez que o professor pode acabar tendo que refazer o trabalho ou fazer as atividades às pressas. A P3 expõe o quão importante a organização é para o desenvolvimento de seu trabalho:

[...] eu gosto das coisas assim bem organizadas né? então assim... uma coisa em cima da hora assim já me deixa frustrada, assim... tudo eu gosto que me avisem com antecedência né? [...] eu vejo assim né, essa indisponibilidade de não poder ficar saindo com as crianças essa organização fora da escola, dentro da escola assim... a 
organização da escola não me chateia muito, não me estressa muito não, né? não me estressa, o que me estressa é o exterior (E,P3).

A P3 enfatiza a organização externa "deixa a desejar", principalmente no que tange à alimentação das crianças e à distribuição das oficinas. Por outro lado, ela elogia a organização interna da escola, que funciona muito bem. De modo complementar, a docente diz que tenta sempre manter seus afazeres organizados, mesmo que para tal necessite diminuir o número de horas dormidas.

$\mathrm{Na}$ mesma direção, P21 enfatiza que também se sente incomodado com a desorganização e compartilhou uma situação relacionada com a desorganização que Ihe causa estresse, em suas palavras:

Olha o que me deixa frustrado é assim quando a gente faz um trajeto $e$ você percebe que não a gente se programa e chega naquela data e não não tem mais então isso me estressa [...]. Olha... tem as programações, vamos supor, tem as apresentações

pedagógicas, aí eles comunicam a gente no começo do ano e a gente faz o trabalho com as crianças, deixa tudo planejadinho quando tá chegando perto do mês aí eu vou e procuro e fala "olha, tá tudo certo vai acontecer mesmo", aí eles vêm me falam "não vai ter mais, não deu certo" mas poxa podia ter avisado né? porque fiquei três meses trabalhando aqui né? já em cima da hora que eu fui perguntar ela fala que não vai mais ter aí eu fico chateado com isso, isso me estressa (E, P21).

O cenário acima descrito representa o confronto entre a realidade idealizada e a realidade vivida. À medida em que o professor percebe que o trabalho real não condiz com suas expectativas, ele se frustra, o que pode desencadear o mal-estar docente. Nesse sentido, Nunes Sobrinho (2007) afirma que:

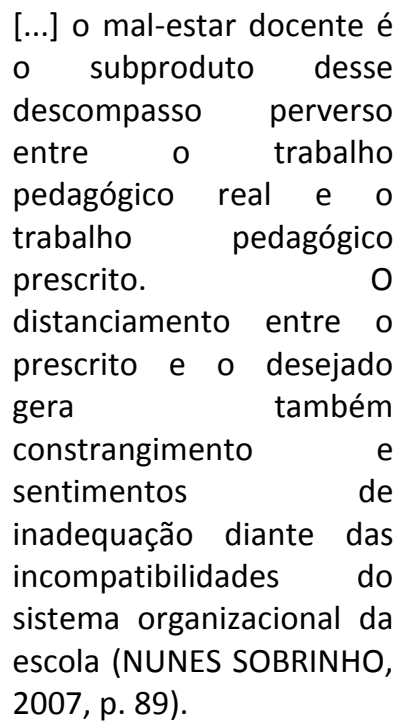

A situação supracitada acaba ainda colocando o professor em uma situação constrangedora, uma vez que cabe a ele explicar o motivo pelo qual a apresentação foi cancelada, frustrando não somente as suas próprias expectativas, mas também as dos alunos e de seus responsáveis. Segue a passagem:

[...] eu nem sei mais o que falar para os alunos porque já estavam todos preparados com uniforme pronto, até os pais também já estavam envolvidas para que aconteça aquele evento e daí de repente não acontece mais, então isso acaba me estressando e acaba estressando os alunos também porque música não se deve ficar mais de três meses [...].

As avaliações externas são elementos relacionados com a demanda laboral e que se constituem como fontes geradoras de tensão entre os docentes. A P20 destacou durante a entrevista a questão da avaliação do professor e do aluno e se diz contra essa prática. No trecho a seguir verificamos como isso é apresentado em sua fala:

[...] eu acho avaliação uma coisa TER-RÍVEL, dentro da escola é uma coisa que prejudica muito os avanços, tanto pro 
professor que é avaliado pela gestão, que ele também é avaliado, como para o aluno porque aí eu acredito naquela história eu faço de conta que eu ensino e você faz de conta que eu aprendo [...] (E, P20).

As avaliações externas seguem um caminho contrário às perspectivas democráticas de avaliação, como emancipação e condição para o desenvolvimento da autonomia da escola, e se configuram como instrumentos com a finalidade de controlar e medir o trabalho docente (CUNHA; BARBOSA; FERNANDES, 2015). Ainda, quando os resultados dos exames não atingem os índices $\mathrm{e}$ as metas, responsabilizam-se unicamente os professores pelos resultados obtidos. Essa responsabilização ou culpabilização é promovida principalmente pelo governo, que faz o uso de estratégias para que uma parte considerável da sociedade apoie e legitime sua política, ocultando as reais condições de trabalho a que os docentes são submetidos (OLIVEIRA, 2006).

A P3 também discorreu sobre as avaliações externas. A docente é responsável pelo 5o ano e comenta o quão desgastante é trabalhar com essa série devido a Prova Brasil. Cabe destacar que o município de Presidente Prudente conta ainda com uma avaliação própria. Nos trechos a seguir verificamos como isso é apresentado na fala de nossa entrevistada:

[...] o quinto ano ele cansa muito a gente, ele é muito desgastante, ele é muito desgastante o quinto ano [...] Assim... que nem eu estou falando, a cobrança do conteúdo, ano de Prova Brasil fica na sua cabeça [...] porque você não vai reprovar um monte de criança, às vezes as crianças chegam com muita defasagem no quinto ano e como que você recupera isso? (E, $\mathrm{P} 3)$.

A professora comentou ainda que as avaliações externas geram cansaço extremo e que ela necessita fazer o uso de folgas para se preservar. Em suas palavras:
Ah... é cansaço, chegando em novembro eu estou um bagaço, chegando assim em novembro, é sempre assim as minhas folgas eu tiro trinta e quatro dias né? [...] aí por exemplo Prova Brasil que é de catorze a vinte cinco de outubro, aí eu pego assim uns três, quatro dias emendado e fico assim na minha casa, descansando né? que nem eu falo, eu tento me preservar né? $(E$, P3).

Conforme a narrativa da P3 a mesma utiliza-se da licença geralmente nos meses de outubro e novembro, meses esses que sucedem as avaliações externas. A professora afirma que esse período de afastamento se faz necessário pois, devido ao cansaço, ela tende a ficar doente. Podemos concluir que esse breve período de afastamento da sala de aula funciona como uma estratégia de prevenção, uma vez que, a docente tem a consciência de o não uso dessa estratégia pode trazer consequências para a sua saúde.

Ainda, sobre as avaliações a P3 menciona que o fato de os alunos não atingirem os resultados esperados lhe frustra, pois o conteúdo foi ensinado e ela se dedicou para que os alunos aprendessem. A fala a seguir reflete essa condição:

[...] às vezes você dá uma prova, você corrige, você vê que as crianças não aprenderam, mas você falou tanto né? [...] eu me dediquei, mas eu não alcancei o resultado que eu queria, às vezes você pensa, mas você fala assim, eu penso assim, "gente eu fiz".

Entretanto, a docente afirma não se sentir culpada pelo baixo rendimento dos alunos, visto que fez tudo que estava em seu alcance apesar das condições adversas, conforme ilustrado no trecho a seguir:

Às vezes eu penso assim "ah, vou fazer isso diferente", mas de me sentir culpada em si não porque assim né? eu dentro das possibilidades 
e tudo, de número de alunos, eu tento dar aquela atenção individual né? [...] eu repenso o meu trabalho.

A sobrecarga de trabalho também pode estar relacionada ao excesso de disciplinas pelas quais os professores são responsáveis, elemento esse evidenciado na fala da P20:

[...] eu tenho professores que ele estão Ensino Fundamental, ele dá aula de português, matemática, física, educação física, de música é... artes, história, geografia, ciências, você consegue reter todos esses conhecimentos? Não, lógico que não, algum você vai ser melhor porque algum vai da sua essência, então como eu ponho um professor pra atribuir tantos conhecimentos se o meu professor não retém todos eles? (E, P20).

A P20 critica o fato de o professor trabalhar com diversas disciplinas, uma vez que ela acredita que o professor não conhecerá o conteúdo de modo aprofundado, e questionada como o professor será capaz de ensinar se ele mesmo não domina o assunto.

Os aspectos referentes as condições sociais e econômicas comparecem em nossa pesquisa com a porcentagem de $32,94 \%$. No que tange à remuneração, o baixo salário foi como uma desvantagem por alguns professores, enquanto há aqueles que informaram trabalhar em tempo integral somente por conta do aumento do salário oriundo da carga complementar:

Nacarato, Varani e Carvalho (2007) afirmam que os salários dos professores são extremamente baixos, o que levou os professores a buscarem saídas, como a ampliação da jornada de trabalho. Essa ampliação faz com que o professor trabalhe os três períodos diários. $\mathrm{Na}$ mesma direção, Lourencetti $(2012$, p. 81) explica que "[...] os professores ganham mal, precisam pegar muitas aulas e/ou ter mais de um emprego para ganhar um pouco melhor, um salário que permita a manutenção e o sustento da casa". Como consequência, "têm pouco tempo para pesquisar, estudar, planejar uma aula diferente" (LOURENCETTI, 2012, p. 81).

Conforme a fala da P3, a mesma diz não ter certeza se atuaria no Programa Cidadescola se o seu salário do turno regular fosse maior. Afirma ainda que, o que a levou a trabalhar no Programa foi o complemento salarial, aspecto esse mencionado por $34,48 \%$ dos docentes de nossa pesquisa sobre as motivações para atuar no Programa.

De modo complementar, cabe destacar que no Programa Cidadescola existe a prática do voluntariado, aspecto esse que evidencia a precarização dos trabalhadores que atuam como oficineiros no contraturno nas oficinas do Programa, tanto do ponto de vista financeiro quanto do pedagógico. Os oficineiros recebem atualmente o valor de $\mathrm{R} \$ 80,00$ por turma mensalmente. Silva e Nóbrega (2013) apontam que a prática do voluntariado tem se tornado uma característica cada vez mais frequente nas políticas atuais e transfere uma obrigação que é do Estado para a população, acentuando a desvalorização e precarização dos trabalhadores, sem assegurar-lhes nenhum benefício

O P21 faz parte do quadro dos oficineiros que atuam no Programa Cidadescola. Inicialmente o professor era contratado por uma empresa, entretanto, hoje ele não possui mais vínculo com a mesma e passou a ser contrato pela verba restante da época que o Cidadescola mantinha parceria com o Programa Mais Educação. Em suas palavras:

Eu estava trabalhando
numa empresa
maravilhosa, ér uma
empresa muito boa, mas
para mim não foi boa esse
ano porque muitos
funcionários tiveram que
ser mandado embora, né?
então é... não teve é... a
empresa não teve
demanda para minha área
específica [...]. Houve uma
redução também de
alunos para poder ir para
o projeto né? no ano
passado ele era imenso,
então é... doeu bastante
como reduziu ou não teve
uma demanda para poder
contratar outros
funcionários, né? então
para mim foi péssimo,
para mim não foi bom


porque lá eu trabalhava registrado né? eu tinha uma garantia e hoje eu não sou registrado hoje eu não tenho essa garantia porque pelo Mais Educação é como uma contratação que a escola faz né? (E, P21).

Conforme a fala do P21, devido à baixa demanda para as aulas de Canto coral e a redução no número de alunos que participam de Cidadescola o mesmo acabou sendo demitido da empresa em que trabalhava. Hoje o professor é contratado com a verba advinda do governo federal, entretanto, perdeu os direitos trabalhistas que possuía quando possuía vínculo com a empresa. Ainda, o docente discorreu sobre a quantia que recebe atualmente como oficineiro e expressa preocupação ao dizer:

[...] essas garantias não existem, é um contrato simples com a escola que ela faz, né? e o que acontece eles só pagam como Mais Educação ele só... para cada oficineiro eles pagam só duzentos e trinta para cada oficineiro então é muito pouco, eu acho muito pouco mesmo, eu vou duas vezes na escola, mas para mim eu vejo que é pouco duzentos e trinta por mês, né? é só duzentos e trinta por mês, né? não é por hora aula, a empresa pagava tanto a hora aula, né? no caso eu era registrado né? então a gente fica mais tranquilo, né? trabalhar registrado e o salário era... era de forma mais correta, né? de forma mais tranquila, que todos os funcionários acham melhor, né? eles valorizam professor, né? (E, P21).

Apesar de o P21 se referir a quantia que ganha como salário, a mesma é apenas uma ajuda de custo para o transporte e alimentação, conforme as regras que regiam o Programa Mais Educação. O docente também enfatiza que é necessário valorizar o professor financeiramente e não somente com elogios, como se vê ilustrado nessa passagem:

[...] como professor a gente quer ser valorizado também na remuneração também, não só falar "professor é bom, que trabalho bom de música" né? mas sim ter uma remuneração boa também, porque se perde todo o valor, se perde todo o vínculo também né? (E, P21).

Apesar da desvalorização financeira, o P21 afirma considerar as crianças e o quanto a música pode contribuir com a formação deles, sendo esse o motivo pelo qual aceita trabalhar recebendo apenas uma ajuda de custo mínima.

[...] o Mais Educação ele trabalha conforme a verba da escola né? então a escola recebe pouca verba também, né? [...] o próprio Mais Educação ele já fala "nós pagamos tanto", então se aquele professor achar que é pouco demais ou se ele achar que é insignificante para ele... ele vai falar "não, olha eu não quero isso para mim, vou procurar serviço", né?, mas eu não penso dessa forma eu penso nas crianças que estão ali, já é um lugar muito distante do centro multiplique as culturas que elas convivem, elas precisam ter esse contato cultural, elas precisam aprender uma nova forma de ensinar música então elas têm que aprender essa cultura também, então assim... se a gente pensar só no dinheiro também... então a gente não leva conhecimento e a educação cada vez mais fica do jeito que está né? todo mundo falando mal da educação, mas não sabe profissionais bons 
tem por trás disso daí $(\mathrm{E}$, P21).

O não reconhecimento também foi apontado como uma desvantagem por uma professora. Esteve (1999, p. 34) ressalta que o reconhecimento do trabalho dos professores geralmente se dá em sentido negativo. Para o autor:

Se um professor faz um trabalho de qualidade dedicando-lhe maior número de horas além das que configuram sua jornada de trabalho, poucas vezes se valoriza expressamente esse esforço suplementar; não obstante, quando o ensino fracassa, às vezes por um acúmulo de circunstâncias ante as quais o professor não pode operar com êxito, o fracasso se personaliza

imediatamente [...]. Além disso, a valorização do trabalho dos professores poucas vezes se baseia em uma razão clara. $\mathrm{O}$ boato $\mathrm{e}$ a reputação, tanto em sentido positivo como negativo, são o veículo habitual do reconhecimento de seu trabalho.

Na contramão, a P3 afirmou que o não reconhecimento não faz parte do seu cotidiadno, principalmente porque conta com o apoio da gestão escolar:

O não reconhecimento lá na escola a gente não vê muito porque assim... a gestão da escola procura agregar, conhecer né o trabalho de todo mundo [...] a direção da escola também apoia né tudo assim né a (nome da articuladora) assim faz tudo para que aconteça da melhor forma né $(E, P 3)$.

O tipo de contrato também pode trazer implicações para a valorização do professor. A P20 discorreu sobre essa questão e criticou o fato de os professores serem "jogados fora a cada dois anos"

[...] tem professores que trabalham, fazem projetos e a cada dois anos são jogadas fora porque acaba o contrato, às vezes por uma obra até divina elas retornam, mas muitas são jogadas fora e chega uma outra rasa que elas não tem essa especialidade $(E$, P20).

A situação descrita pela P20 é a realidade de muitos professores temporários, que apesar de desenvolverem a mesma função e cumprirem os mesmos deveres que os efetivos, não usufruem dos mesmos direitos trabalhistas. Isso se dá porque é mais econômico para a Administração do município contratar um professor por um prazo determinado, uma vez que esse não recebe salário no período das férias escolares e não possui plano de carreira. Essa realidade além de desencadear o sofrimento nos professores contratados, traz implicações para o desenvolvimento das atividades, conforme mencionado na narrativa da P20. Cabe lembrar que o salário desses professores também se difere dos professores efetivos que atuam no Cidaescola.

Outro aspecto abordado pelas participantes da pesquisa foi a função da escola e o que ela representa para a sociedade. A P20 critica o fato de os alunos não compreenderam o porquê de irem à escola, vejamos o seu argumento:

[...] a pessoa não tá situada, ela não tá entendendo o que ela está fazendo ali, a escola ela está aberta pra quem não tem o que fazer com aquela criança, a criança vem sem entender o que ela tá fazendo, ela não tem antes de chegar à escola alguém que mostre pra ela o porquê que ela tem que ir pra escola, os benefícios que a escola vai contribuir, então nós temos aqui uma criança que se sente jogada e o professor tem que saber trabalhar com isso, com 
essa carência, com essa depressão [...].

A narrativa da P20 é um campo fértil para debates e possui como eixo central o papel da escola. A docente critica a posição da sociedade frente o papel da escola, assunto esse discutido por Batista e Codo (2006, p. 74):

[...] a escola foi chamada a desempenhar diversos papéis, tais como o de favorecer a integração social, e propiciar a integração

socioeconômica dos indivíduos. A escola também já foi tida, e ainda hoje é tida por muitos no Brasil, como a possibilidade de tirar as crianças pobres da rua exercendo sobre elas um tipo de disciplinamento, "salvaguarda" da caída dos jovens no mundo do crime [...]. Os professores estão no meio do "fogo", esfacelados eles mesmos [...] pela produção na sociedade de uma ética do trabalho moderna que se contrapõe a uma outra que ainda luta pela sobrevivência. Perante essa realidade, qual $o$ papel da escola? ... ninguém sabe ao certo.

De modo complementar, Assunção e Oliveira (2009) explicam que quanto mais complexas as demandas às quais a escolas precisam responder, mais complexas são atividades dos professores, que muitas vezes se veem diante situações quais não se sentem preparados. As autoras afirmam ainda que, quanto mais carente o ambiente em que a escola está inserida, maior é a demanda que chegam até elas e por consequência, aos professores.

Na mesma direção que a a P3 também se queixa sobre o fato de os alunos não terem consciência do porquê frequentam a escola e possuírem uma visão equivocada de que estudar é prazeroso. O P21 também fez menção a mídia em sua narrativa. $O$ docente explica que muitas vezes as pessoas não analisam a real situação e acabam por acreditar nas informações divulgadas pelos meios de comunicação
[...] impõe a mídia impõe então a pessoa sem saber o porquê da mídia sem entender a mídia ela acaba indo junto com a mídia então já era esse transtorno que estamos vivendo hoje com certeza a mídia é o grande vilão $(E$, P21).

Esteve (1999) reflete sobre o tratamento que a figura do professor recebe da mídia. 0 autor pontua que que existem duas linhas contrapostas nos enfoques do professor: "de um lado apresenta-se a profissão docente como uma profissão conflitiva; de outro, [...] o enfoque que apresenta à docência como uma atividade idílica, centrada quase exclusivamente na relação interpessoal com os alunos (ESTEVE, 1999, p. 39). No que tange ao primeiro enfoque 0 autor explica que os principais componentes dessa imagem conflitiva seriam: "as situações de violência física nas aulas, implicando professores, pais e alunos; as demissões de conflito provocadas por confrontos ideológicos ou discrepância de valores; as baixas retribuições dos professores, sobretudo no aspecto salarial; a falta de meios materiais, instalações, aquecimento, material escolar, etc. com que se exerce à docência" (ESTEVE, 1999, p. 40). Por sua vez, o enfoque idílico apresenta uma imagem atraente da profissão docente, muito distante da realidade. $O$ professor aparece relacionado com a imagem de amigo e conselheiro.

A questão da avaliação do Programa também foi um dos elementos abordados, mais especificamente na entrevista com a P3. A professora apresenta que em geral, os docentes, não possuem a oportunidade de conversar com a direção do Programa, ação essa destinada especialmente aos articuladores. Apesar de os articuladores fazerem a "ponte" entre os docentes e a direção do Programa, é fundamental que os professores sejam ouvidos também diretamente pela gestão do Programa, visto que são eles que atuam no "chão da escola" e conhecem a real situação da sala de aula.

Mas há também professores que mencionaram o fato de serem reconhecidos, pois acreditam no seu trabalho e receberam incentivos por parte da escola e da SEDUC. O P21 discorreu sobre o reconhecimento dos alunos $\mathrm{e}$ dos pais dos mesmos, sendo que muitas vezes 
esse reconhecimento acontece fora do ambiente escolas. Vejamos essa passagem do P21:

Quando eu passo na rua que eu vejo a criança me gritando pra mim é um orgulho, às vezes eu tô com minha esposa lá no shopping, passa as crianças e eles gritam mesmo, "o professor", os pais vem até mim e agradecem "meu filho mudou nisso" e isso pra mim é um reconhecimento, é muito bom pra mim, não tem nada que reclamar não (E, P21).

Esse reconhecimento dos pais dos alunos e dos próprios alunos produz no professor um sentimento de satisfação e de orgulho de fazer parte da equipe do Programa. Em suas palavras:

Olha, ao longo desses anos que eu venho trabalhando com música é o projeto mais fantástico que eu já trabalhei, é um projeto que eu tenho orgulho de fazer parte da equipe que eu atuo, então eu vejo só melhoras, eu não vejo assim regressão, eu só vejo que o projeto está pro-gre-dindo e crescendo, então para mim é fantástico tá fazendo parte desse projeto, estar junto com essas crianças (E, P21).

O professor comentou após o término da entrevista que o vídeo da apresentação do aniversário de oito anos do Programa Cidadescola chegou até a cantora Kell Smith (interprete da música "Era uma vez", apresentada pelas crianças do Programa) e que ela afirmou que virá cantar a música junto às crianças. Esse acontecimento definitivamente é um reconhecimento do trabalho desenvolvido, que pode contribuir com o bem-estar docente.

Conforme os dados apresentados, as condições organizacionais, sociais e econômicas dos professores foram os elementos mencionados o maior número de vezes pelas docentes, sendo a carga horária e demanda laboral a principal queixa das professoras, aspectos esses que resultam em cansaço e em desgaste físico e psicológico. Os baixos salários e a desvalorização também compareceram nas falas das participantes da pesquisa. Entretanto, há aqueles que se dizem satisfeitos com o Programa e relatam os aspectos positivos em atuar como professor na escola de tempo integral.

\section{CONCLUSÕES}

Diante do objetivo do presente trabalho que foi investigar e analisar as condições de trabalho dos professores que atuam com a jornada ampliada no Programa Cidadescola, foi possível identificar três categorias que prevaleceram nas falas dos professores, a partir das análises dos resultados a saber: participação docente no processo de implantação do Programa de Educação Integral Cidadescola; infraestrutura escolar e realização do trabalho docente e condições organizacionais, sociais e econômicas dos professores. Nesse sentido, é possível perceber a necessidade premente da assunção de macro e micropolíticas educacionais, visto que essas determinam as condições e a organização do trabalho docente, podendo agir como catalisadores do adoecimento dos professores.

Acreditamos que os aspectos aqui apresentados podem contribuir como subsídios para as discussões sobre a educação em tempo integral e as condições de trabalho dos professores que atuam na escola pública de tempo integral. Por sua vez, cabe atentar-se para as limitações do estudo. O número limitado de participantes (21 professoras) não nos permite afirmar que as condições de trabalho aqui apresentadas são válidas para toda a rede municipal de ensino do município de Presidente Prudente. Desse modo, sugerimos que o trabalho seja retomado com uma quantidade mais ampla de sujeitos, principalmente no que tange à entrevista, visto que apenas 3 docentes concordaram em participar da mesma. Ainda, o presente trabalho abre espaços para novas discussões e questionamentos como: a redução do papel do Estado na responsabilidade para com a Educação, parcerias público-privadas e projetos educacionais com cunho neoliberal. Nesse sentido, estamos diante de um tema abrangente, que se constitui como um campo fértil para novas contribuições e reflexões.

A análise nos permitiu concluir que, as condições de trabalho docente dos professores 
que atuam no Programa Cidadescola carecem de aprimoramento. Nesse sentido, é necessário atentar-se para a relação entre as condições de trabalho e os efeitos sobre a saúde dos professores, o sofrimento no trabalho docente e a qualidade de vida desses profissionais. Portanto, a implementação de um programa que amplia o tempo de permanência de estudantes nas escolas públicas exige o investimento nas condições de trabalho dos professores, para que, superada essas deficiências, a educação integral possa, de fato, ser concretizada.

\section{AGRADECIMENTOS}

Agradecimentos à FAPESP e à CAPES pelo financiamento da pesquisa de Mestrado da qual decorreu este artigo. Processo no 2017/11415-8, Fundação de Amparo à Pesquisa do Estado de São Paulo (FAPESP). O presente trabalho foi realizado com apoio da Coordenação de Aperfeiçoamento de Pessoal de Nível Superior Brasil (CAPES) - Código de Financiamento 001. As opiniões, hipóteses e conclusões ou recomendações expressas neste material são de responsabilidade do(s) autor(es) e não necessariamente refletem a visão da FAPESP e da CAPES. Os autores declaram não haver qualquer potencial conflito de interesse que possa interferir na imparcialidade deste trabalho científico.

\section{REFERÊNCIAS}

ASSUNÇÃO, A. Á.; OLIVEIRA, D. A. Intensificação do trabalho e saúde dos professores. Educação \& Sociedade, Campinas, v. 30, n. 107, p. 349-372, mai./ago. $2009 . \quad$ Disponível em: http://www.scielo.br/pdf/es/v30n107/03.pdf.

Acesso em: 20 jan. 2018. https://doi.org/10.1590/S010173302009000200003

BARBOSA, M. E. F.; FERNANDES, C. A escola brasileira faz diferença? Uma investigação dos efeitos da escola na proficiência em matemática dos alunos da 4a série. In: FRANCO, C. (Org.). Avaliação, ciclos e promoção na educação. Porto Alegre: Artmed, 2001. p. 1-23.

BATISTA, A. S.; CODO, W. Crise de identidade e sofrimento. In: CODO, W. (coord.). Educação: carinho e trabalho - Burnout, a síndrome da desistência do educador, que pode levar à falência da educação. Petrópolis: Vozes, 2006. p. $60-85$.
BATISTA, A. S.; ODELIUS, C. C. Infra-estrutura das escolas e burnout dos professores. In: CODO, W. (coord.). Educação: carinho e trabalho - Burnout, a síndrome da desistência do educador, que pode levar à falência da educação. Petrópolis: Vozes, 2006. p. $324-332$.

BATISTA, A. S.; ODELIUS, C. C. Gestão democrática nas escolas e burnout nos professores. In: CODO, W. (coord.). Educação: carinho e trabalho - Burnout, a síndrome da desistência do educador, que pode levar à falência da educação. Petrópolis: Vozes, 2006. p. $333-337$.

BRASIL. Lei n. 9.394, de 20 de dezembro de 1996. Estabelece as Diretrizes e Bases da Educação Nacional. Diário Oficial da União, Brasília, DF, 23 dez 1996. Acesso em: 26 jan. 2018.

BRASIL. Lei no 10.172, de 09 de janeiro de 2001. Aprova o Plano Nacional de Educação e dá outras providências. Diário Oficial da União, Brasília, DF, 10 jan. 2001. Acesso em: 15 fev. 2018.

BRASIL. Decreto no. 6.253, de 13 de novembro de 2007. Dispõe sobre o Fundo de Manutenção e Desenvolvimento da Educação Básica e de Valorização dos Profissionais da Educação FUNDEB, regulamenta a Lei no 11.494 , de 20 de junho de 2007, e dá outras providências. Diário Oficial da União, Brasília, DF, 14 nov. 2007a. Acesso em: 19 fev. 2018.

BRASIL. Ministério da Educação. Plano de Desenvolvimento da Educação: Razões, Princípios e Programas. Brasília, DF, 2007b. Acesso em: 19 de mar. 2018.

CAVALIERE, A. M. Anísio Teixeira e a educação integral. Paidéia, Ribeirão Preto, v. 20, n. 46, p. 249-259, ago. 2010. Disponível em: http://www.scielo.br/pdf/paideia/v20n46/11.pdf Acesso em: 15 jan. 2018. https://doi.org/10.1590/s0103$\underline{863 \times 2010000200012}$

CUNHA, M. I. da. Profissionalização docente: contradições e perspectivas. In: VEIGA, I. P. A.; CUNHA, M. I. (Orgs.). Desmistificando a profissionalização docente. Campinas: Papirus, 1999. p. 127-147. 
CUNHA, R. C. O. B.; BARBOSA, A; FERNANDES, M. J. S. Implicações das avaliações externas para o trabalho docente coletivo. Estudos em Avaliação Educacional, São Paulo, v. 26, p. 386-416, 2015. Disponível em: http://publicacoes.fcc.org.br/ojs/index.php/eae/ article/view/3288. Acesso em: Acesso em: 25 jun. 2018. https://doi.org/10.18222/eae266203288

ESTEVE, J. M. O mal-estar docente: a-sala-de-aula e a saúde dos professores. Bauru/SP: EDUSC, 1999.

GIROUX, H. Escola crítica e política cultural. São Paulo: Cortez; Autores Associados, 1987.

HYPOLITO, Á. M. Trabalho docente na educação básica no Brasil: as condições de trabalho. In: OLIVEIRA, D. A; VIEIRA, F. G. (org). Trabalho na educação básica: a condição em sete estados brasileiros. Belo Horizonte: Fino Traço Editora, 2012. p. 211-230.

HYPOLITO, Á. M. Currículo e projeto políticopedagógico: implicações na gestão e no trabalho docente. Cadernos de Educação, Brasília, v. 18, n. 26, jan./jun. 2014. p. 11-26.

HYPOLITO, Á. L. M. Trabalho docente e profissionalização: sonho prometido ou sonho negado? In: VEIGA, I. P. A.; CUNHA, M. I. (Org.). Desmistificando a profissionalização do magistério. Campinas: Papirus, 1999. p. 81-100.

JACINTO, L. T; HOBOLD, M.S. Trabalho docente: desafios e perspectivas na relação professoraluno no ensino médio. Educação \& Linguagem, São Paulo, v. 15, n. 25, p. 277-301, 2012. Disponível em: https://www.metodista.br/revistas/revistasims/index.php/EL/article/view/3358. Acesso em: 5 jun. 2019 . https://doi.org/10.15603/21761043/el.v15n25p277-301

LOURENCETTI, G. C. A intensificação no trabalho docente: repercussões no cotidiano da sala de aula. In: MARQUES, M. A. de R. B.; DAVID, A. (Org.). As interfaces da profissão docente: formação, trabalho, práticas, currículo e avaliação. Araraquara: Junqueira \& Marin Editores, 2012, p. 68-92.
LUDKE, M.; ANDRÉ, M. E. D. A. Pesquisa em educação: abordagens qualitativas. São Paulo: Editora Pedagógica e Universitária- EPU, 1986.

MILES, M. B.; HUBERMAN, A. M.; SALDAÑA, J. Qualitative Data Analysis: A Methods Sourcebook. London: Sage Publications Ltd. 2014.

MINAYO, M. C. S. O trabalho de campo: contexto de observação interação e descoberta. In: DESLANDES, S. F; GOMES, R.; MINAYO, M. C. S. (Org). Pesquisa social: teoria, método e criatividade. 28. ed. Petrópolis, RJ: Vozes, 2009. p. 61-78.

NACARATO, A. M.; VARANI, A.; CARVALHO, V. de. O cotidiano do trabalho docente: palco, bastidores e trabalho invisível ... abrindo as cortinas. In: GERALDI, M. G.; FIORENTINI, D.; PEREIRA, E. M. de A. Cartografias do trabalho docente. Campinas (SP): Mercado de letras; 2007. p. 73-104.

NUNES SOBRINHO, F. P. O stress do professor do Ensino Fundamental: o enfoque da ergonomia. In: LIPP, M. L. (org.). O stress do professor. 5. ed. Campinas: Papirus, 2007. p. 81-94.

OLIVEIRA, D. A. Regulação educativa na América Latina: repercussões sobre a identidade dos trabalhadores docentes. Educação em Revista, Belo Horizonte, v. 44. p. 209-227. dez. 2006. Disponível em: http://www.scielo.br/scielo.php?pid=S010246982006000200011\&script=sci_abstract\&tIng=p t. Acesso em: 20 mar. 2018. https://doi.org/10.1590/S010246982006000200011

OLIVEIRA, D. A.; ASSUNCAO, A. Á. Condições de trabalho docente. In: OLIVEIRA, D. A.; DUARTE, A.; VIEIRA, L. M. F. (Orgs.). Dicionário trabalho, profissão e condição docente. Belo Horizonte: UFMG/Faculdade de Educação, 2010. Disponível em: http://www.gestrado.net.br/?pg=dicionarioverbetes. Acesso em: 11 ago. 2018

OLIVEIRA, D. A.; VIEIRA, L. F. Condições de trabalho docente: uma análise a partir de dados de sete estados brasileiros. In: OLIVEIRA, D. A.; VIEIRA, F. G. (org). Trabalho na educação básica: a condição em sete estados brasileiros. Belo Horizonte: Fino Traço Editora, 2012. p. 153-190. 
REBOLO, F. Fontes e dinâmicas do bem-estar docente: os quatro componentes de um trabalho felicitário. In: REBOLO, F.; TEXEIRA, L. R. M.; PERRELLI, M. A. S. (Org.). Docência em questão: discutindo trabalho e formação. Campinas, SP: Mercado das Letras, 2012. p. 23-60.

SILVA, M. A. da; NÓBREGA, S. A. O programa Mais Educação e sua política de formação e trabalho docente: a experiência de Caruaru. In: SIMPÓSIO BRASILEIRO DE POLÍTICA E ADMINISTRAÇÃO DA EDUCAÇÃO, 26., Recife, 2013. Anais... Recife: ANPAE, 2013. Acesso em: 25 mar. 2019. Disponível em: http://www.anpae.org.br/simposio26/1comunica coes/MariaAngelicadaSilva-ComunicacaoOralint.pdf.

SILVA, N. S. Formação de professores e a Escola de Tempo Integral no município de Araçatuba: práticas, desafios e possibilidades. 2016. $189 \mathrm{f}$. Dissertação (Mestrado em Educação). Presidente Prudente: 2016.

TARDIF, M. LESSARD, C. O trabalho docente: elementos para uma teoria da docência como profissão de interações humanas Petrópolis, RJ: Vozes, 2009. 